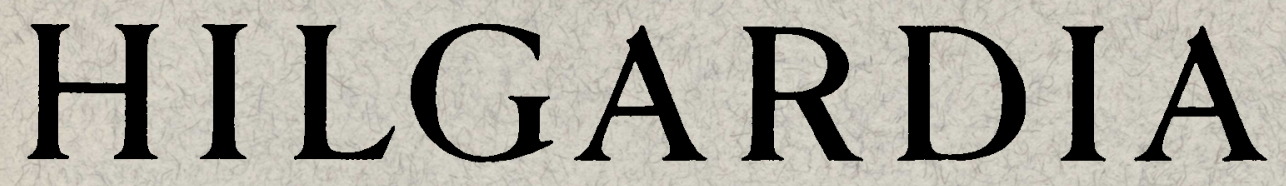

A Journal of Agricultural Science Published by the California Agricultural Experiment Station

\title{
SOME EXPERIMENTS ON THE DECONTAMINATION OF SOILS CONTAINING STRONTIUM 90
}

R. K. SCHULZ, J. P. MOBERG, and ROY OVERSTREET 
The possibility that large areas of the landscape could becone contaminated with strontium 90 through fallout or reactor accidents has necessitated studies of means of decontaminating soils containing radio-strontium. In this work three possible methods were investigated: 1) displacement by electrolytes and leaching; 2) physical immobilization using asphalt preparations; and 3) placement at depth.

Of the various electrolytes used, ferric chloride and hydrochloric acid were most effective. The use of the electrolytes followed by leaching with 5 feet of irrigation water displaced up to 90 per cent of the $\operatorname{Sr} 90$ below the surface 6 inches. This, however, was not sufficient decontamination so that the land could be put back into agricultural use. In addition the procedure is very expensive.

By spraying the soil surface with asphalt, it was found that 97 per cent of the Sr 90 could be removed by peeling off the hardened crust. When the crust was cultivated into the soil profile, however, the Sr 90 gradually became available to plants.

In order to investigate the possibility of reducing the uptake of Sr 90 by deep plowing, experiments were conducted in lysimeters in which the isotope was placed in bands at different depths in the soil. When the soil was cropped to barley, a marked reduction of uptake of Sr 90 with depth of placement was observed. In irrigated barley the content of strontium 90 per gram of plant material was reduced tenfold when the depth of placement was increased from 2 inches to 2 feet. 


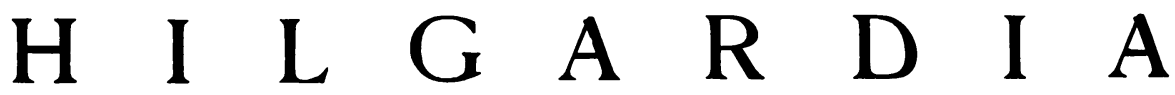

A Journal of Agricultural Science Published by

the California Agricultural Experiment Station

\section{SOME EXPERIMENTS ON THE DECONTAMINATION OF SOILS CONTAINING STRONTIUM $90^{1}$}

\section{R. K. SCHULZ, ${ }^{2}$ J. P. MOBERG, ${ }^{3}$ and ROY OVERSTREET ${ }^{4}$}

\section{INTRODUCTION}

A STUDY of methods for decontaminating soils that contain dangerous amounts of $\mathrm{Sr} 90$ is becoming quite urgent as the use of atomic energy for industrial and military purposes is constantly expanded. The possible contamination of soils by military explosions is well recognized and accidental releases of Sr 90 to the landscape through reactor accidents are definite if somewhat remote possibilities.

When $\mathrm{Sr}$ is adsorbed on colloidal clay surfaces, it is held in an exchangeable form with an adsorption energy similar to that of calcium (Krishnamoorthy and Overstreet, 1950). ${ }^{5}$ Also, it has been shown that when $\mathrm{Sr} 90$ is added to soil, very little of it is fixed in a nonexchangeable form, at least during short periods of time (Schulz, Overstreet, and Babcock, 1958). From this knowledge and direct laboratory experiments (Overstreet, 1956), it is known that for some time following a deposition of water-soluble Sr 90 by way of fallout, essentially all of the isotope remains in an exchangeable form in the immediate surface of the soil. This, of course, is a temporary condition, because such agents as cultivation, drying and cracking, burrowing. rodents, worms, et cetera, will slowly incorporate the element into the soil profile. Thus incorporated in the soil, the $\mathrm{Sr} 90$ is readily available to plants. Many investigators (Neel et al., 1956; Martin et al., 1957 ; Jacobson and Overstreet, 1947 ; Guliakin and Yudintseva, 1957) have shown that relatively large amounts of the radioisotope are taken up and translocated by plants growing in soils contaminated with $\mathrm{Sr} 90$.

The general objective of the work reported here has been the decontamination of soils which have received a surface application of carrier-free $\mathrm{Sr}$ 90. The researches have been conducted along three distinct lines and each approach is reported separately.

\footnotetext{
${ }^{1}$ This paper is based on work performed under contract number AT-(11-1)-34, Project 23, with the U. S. Atomic Energy Commission. Received for publication October 31, 1958.

${ }^{2}$ Assistant Specialist in Soils and Plant Nutrition in the Experiment Station, Berkeley.

${ }^{3}$ Research Assistant, Department of Soils and Plant Nutrition, Berkeley.

+ Professor of Soil Chemistry and Soil Chemist in the Experiment Station, Berkeley.

"See "Literature Cited" for citations referred to in text by author and date.
} 


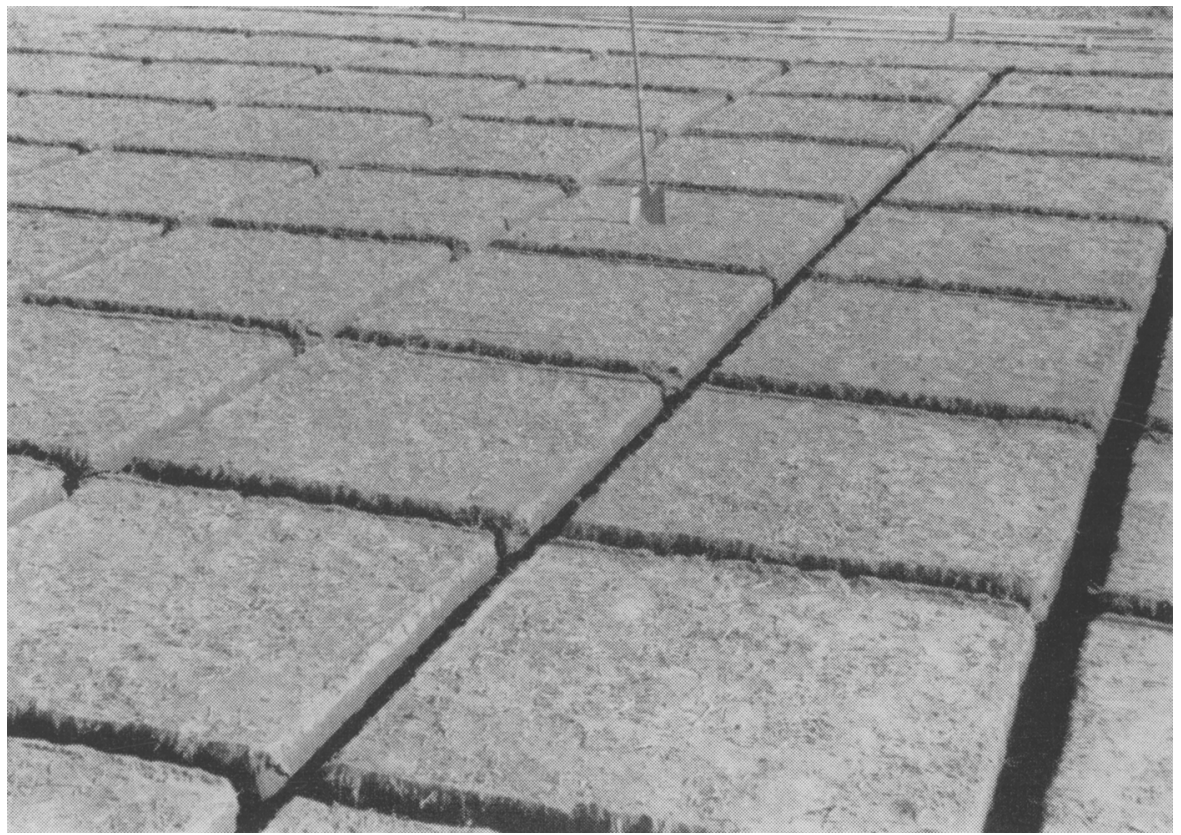

Fig. 1. Construction of plots at Burris Park Field Station.

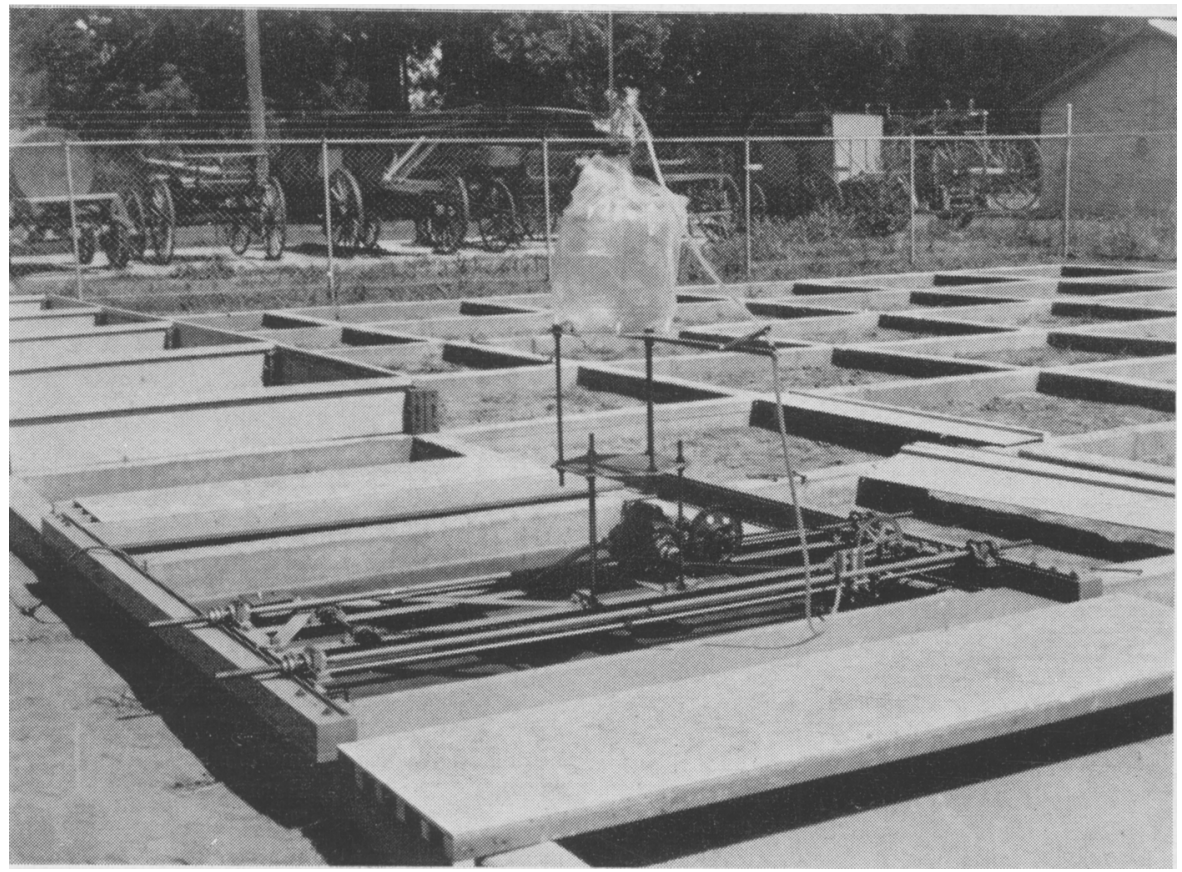

Fig. 2. View of Burris Park Field Station showing Sr 90 applicator in foreground. 
1) The first procedure was the heavy application of electrolytes followed by extensive leaching with water. By this means, it was hoped that the radioisotope would be released from the soil particles and moved to lower depths in the soil profile.

2 ) The second procedure was based on the physical immobilization of the Sr 90. The contaminated soils were sprayed with an asphalt emulsion. By this means, the surface soil particles containing the isotope were embedded in a layer of asphalt and thus could be removed from the soil or plowed into the profile.

3) In the third procedure, the effect of depth of placement of the $\mathrm{Sr} 90$ on its availability to plants was studied. The intention was to gain information on the possibility of reducing plant uptake of Sr 90 by deep plowing.

\section{ADDITION OF ELECTROLYTES FOLLOWED BY LEACHING}

This method is analogous to procedures used in the reclamation of soils containing undesirable amounts of adsorbed sodium and for which there is a considerable background of theory and experience. It was thought that additions of strong replacing ions such as $\mathrm{H}^{+}, \mathrm{Ca}^{++}$, and $\mathrm{Fe}^{+++}$might effect a release of the $\mathrm{Sr} 90$ to the soil solution. Thus released, the strontium conceivably could be displaced by leaching to depths in the soil profile below the major part of the root zone.

\section{Experimental Procedure and Results}

The experiments were carried out at two field stations located in areas of different soil and climate. One station is located at Burris Park, in Kings County, California. The soil of this station is a deep, very fine sandy loam of the Hanford series. The chemical analysis of the soil is given in table 1. Four borings and a random surface composite were analyzed in order to investigate the variability of the soil. The annual rainfall at this location is about 10 inches. The other station was located at the Hopland Field Station of the University of California in Mendocino County, California. The soil here is Yorkville loam with a depth of approximately 4 feet. The analysis of this soil is given in table 2 . The annual rainfall at this location is about 40 inches.

Each station consists of 49 plots $6^{\prime} \times 6^{\prime}$, laid out in a checkerboard fashion. In the construction of the plots, ditches were machine-dug $6^{\prime \prime}$ wide and $30^{\prime \prime}$ deep (see figure 1), forms were placed around the top of the plots and concrete was poured to give a curbing extending 6 " above the ground and $30^{\prime \prime}$ into the soil profile. The completed Burris Park Station is shown in figure 2.

In order to apply the Sr 90 uniformly to the soil, a mechanical applicator was constructed. It is shown in the foreground in figure 2. Basically it consisted of a traveling sprinkler head which traverses the plots at 25 feet per minute while the whole assembly moves perpendicularly to the path of the sprinkler at the rate of 1 foot per minute. The sprinkler head was constructed of lucite and contained 17 holes in line spaced 1/4 inch apart. The Sr 90 was supplied to the sprinkler in carrier-free solution from a constant head bottle. At the Burris Park station a sprinkler with 0.0350" diameter holes was used, which delivered the solution at a rate of 1.68 liters per minute. This rate was 


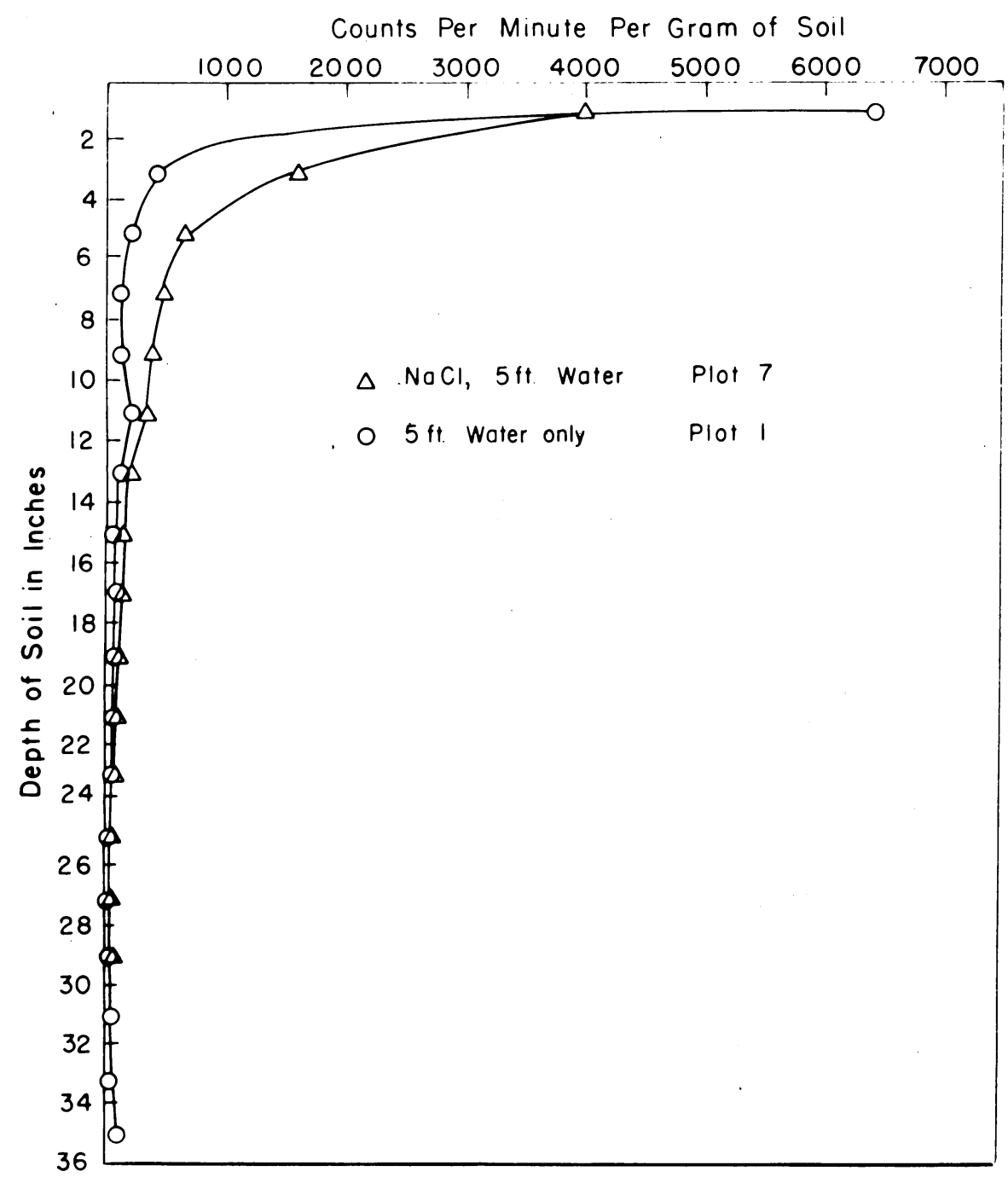

Fig. 3. Distribution of Sr 90 in Hopland soil profile after treatment.

too high, causing running of the solution on the soil surface and resulting in a somewhat uneven application of $\mathrm{Sr} 90$. At the Hopland station a new sprinkler with $0.0250^{\prime \prime}$ diameter holes was used, which gave an application rate of 0.98 liter per minute and resulted in a very even distribution of Sr 90 on the soil surface.

After the Sr 90 solution had been applied, the plots were allowed to dry and the following electrolytes were added in solution form: $\mathrm{HCl}, 14.9$ tons per acre; $\mathrm{FeCl}_{2}, 22.1$ tons per acre; $\mathrm{H}_{2} \mathrm{SO}_{4}, 20$ tons per acre; $\mathrm{CaCl}_{2}, 22.6$ tons per acre; and $\mathrm{NaCl}, 23.8$ tons per acre. As soon as the solutions had entered the soil, the plots were irrigated until 5 feet of water had been applied. Fol- 


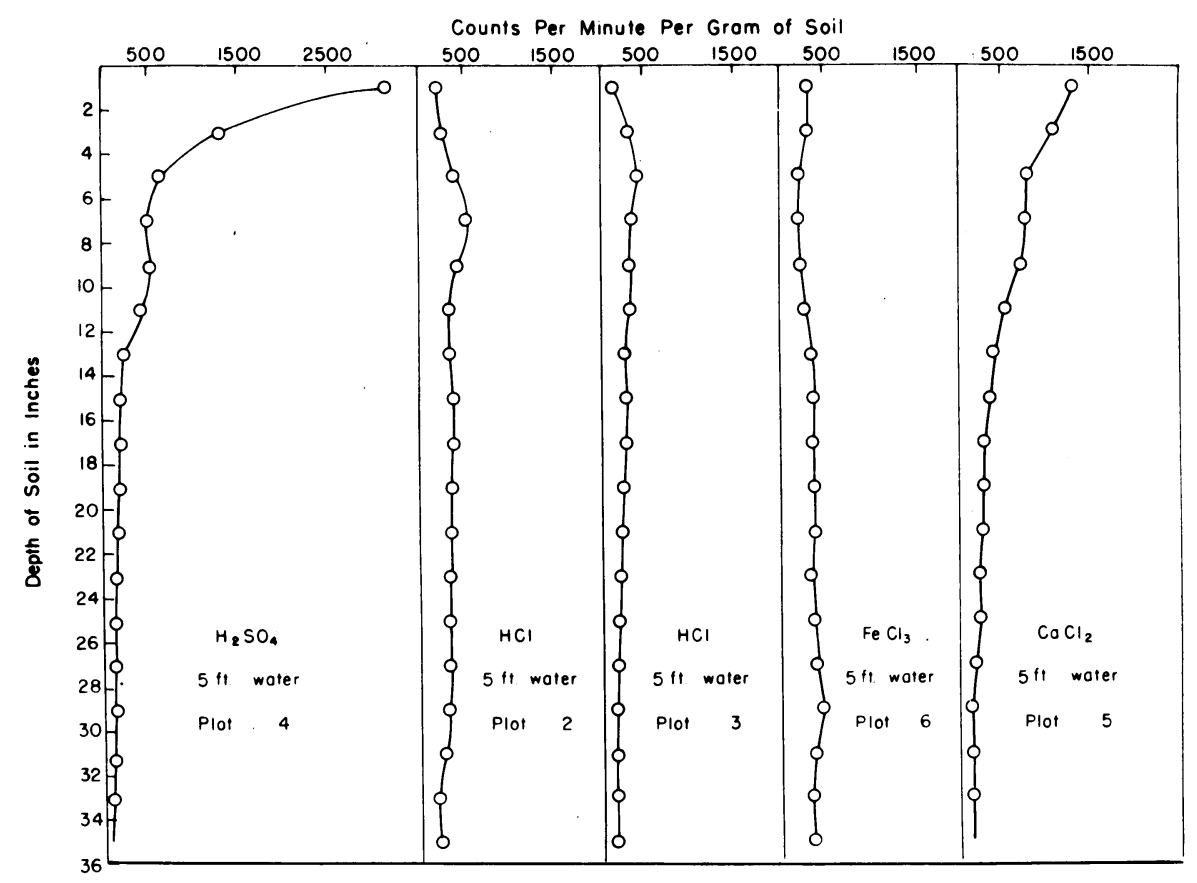

Fig. 4. Distribution of $\mathrm{Sr} 90$ in Hopland soil profile after treatment.

lowing the application of the treatments, two soil cores were drawn from each plot and the distribution of the $\mathrm{Sr} 90$ was determined. The results are presented in figures 3 to 6 .

Two HCl plots were included to give information on the expected variability. Good duplication was obtained at the Hopland station, but a fairly large variability was encountered at the Burris Park station.

\section{Discussion and Conclusions}

It is evident from figures 3 to 6 that $\mathrm{HCl}$ and $\mathrm{FeCl}_{3}$, were most effective in removing the Sr 90 from the surface horizons but the result differed markedly at the two stations. The observations are summarized in table 3 where the fractions of applied Sr 90 remaining in the various horizons are presented for each treatment. In general it must be concluded that the decontamination of soils by any of the above treatments would be very expensive. As an example, agricultural calcium chloride costs approximately $\$ 100$ per ton. Thus, the $\mathrm{CaCl}_{2}$ treatment would cost about $\$ 2,200$ per acre.

\section{PHYSICAL IMMOBILIZATION OF THE Sr 90}

In view of the prohibitive cost of soil decontamination by chemical treatments and leaching, the possibility of physical removal or immobilization of surface contamination was investigated. Since in areas contaminated by way of fallout the $\mathrm{Sr} 90$ is held initially in the immediate surface of the soil 


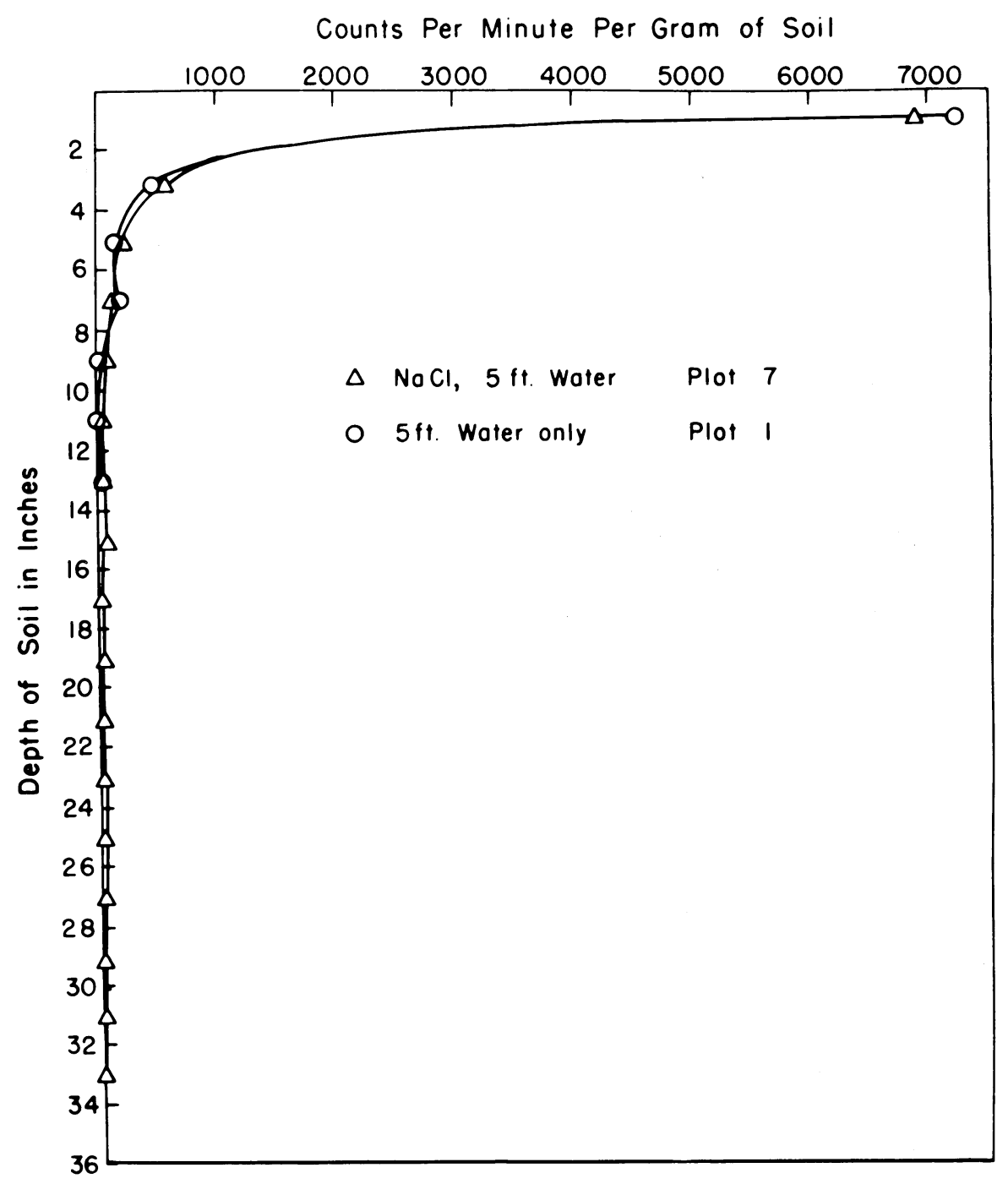

Fig. 5. Distribution of Sr 90 in Burris Park soil profile after treatment.

profile, it appeared feasible to spray the land with some material which would enclose and immobilize the radioactivity.

\section{Experiments and Results}

With the above general approach in mind, a number of experiments were conducted with asphalt emulsions prepared by the American Bitumuls Company. Four preparations were tested. Two were water emulsions of asphalt which were diluted with 2 parts water prior to use. The trade names of the products are Lakold Waterproofing and Bitusize L3L. The third preparation, RCI, was a naphtha solution of asphalt diluted with an equal part of 


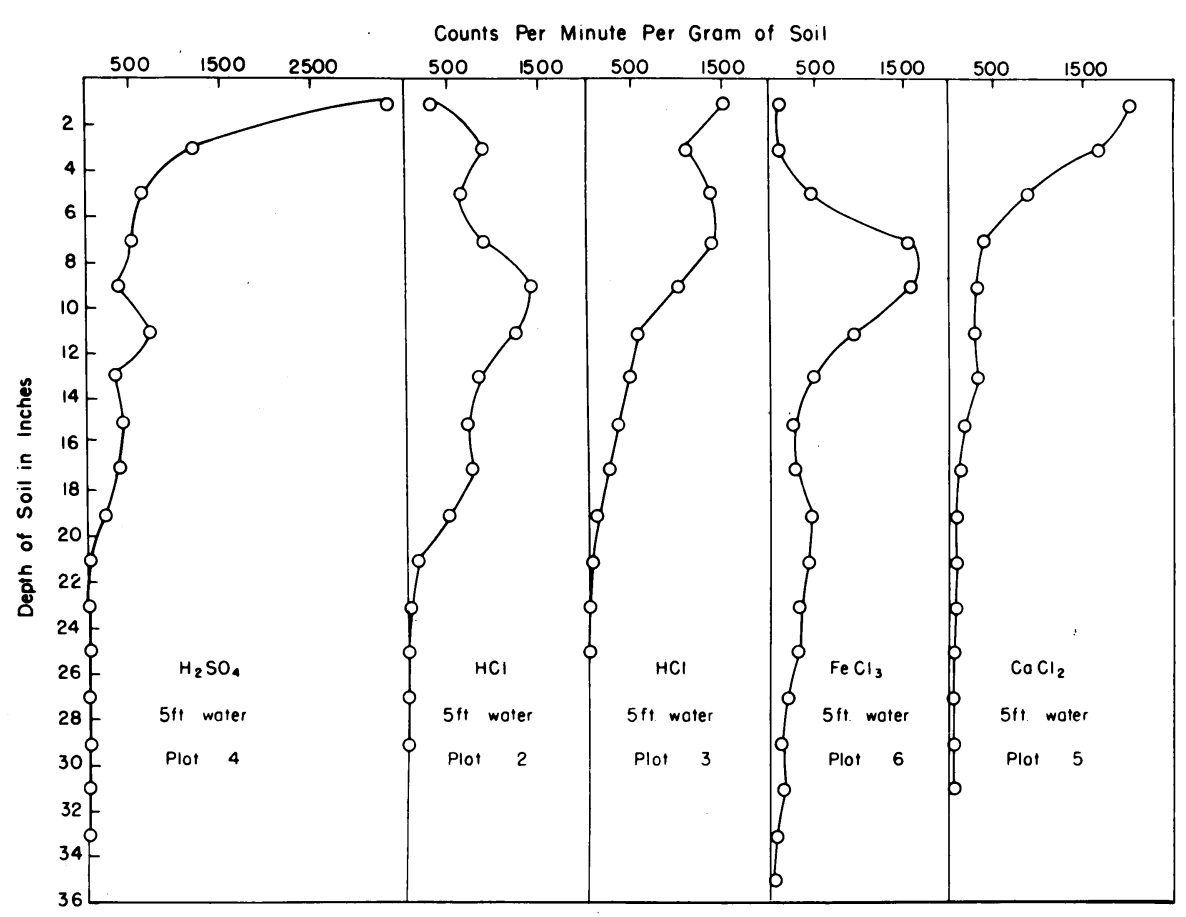

Fig. 6. Distribution of Sr 90 in Burris Park soil profile after treatment.

paint thinner. The fourth product, MCI, was similar to the third, but the asphalt was dissolved in a less volatile petroleum product. This solution was diluted with 1 part kerosene prior to use.

When the Lakold preparation was sprayed on a soil surface contaminated with $\mathrm{Sr} 90$ and allowed to harden, 97 per cent of the radioactivity could be removed by peeling off the hardened crust. Apparently the contaminated surface particles of soil were imbedded in a layer of asphalt.

The question arose as to whether the radioactivity so fixed in the asphalt was available to plants. In order to investigate this, 110 pound batches of Columbia v.f.s.l. were weighed into galvanized iron containers. For each treatment the surface was contaminated with carrier-free $\mathrm{Sr} 90$ at the rate of 1 micro-curie per square inch, using the device described in the previous section. Following this, the soil was allowed to dry and the various asphalt preparations were applied by spraying. The same device as used for applying the $\mathrm{Sr} 90$ was employed, except that the asphalt was fed to the moving sprinkler head under a nitrogen pressure of 5 pounds per square inch. This resulted in an application of $280 \mathrm{ml}$ of emulsion per square foot.

The asphalt crust was allowed to harden for one week and then was turned under and mixed throughout the soil. After this, the soil was planted to barley and the uptake of $\mathrm{Sr} 90$ compared with that in the control was determined at periods of 18 days and 67 days after planting.

One of the preparations, MCI, was found to be toxic to plants. The results of the other three preparations are summarized in table 4 . 


\section{Conclusions}

As may be seen from table 4 the Lakold emulsion was by far the most effective in immobilizing the Sr 90 . With passage of time, however, the radioactivity fixed with this emulsion became more available to plants.

The above experiments indicate that very effective decontamination of soils can be accomplished by spraying a Sr 90 contaminated soil surface with an asphalt emulsion, allowing it to harden, and peeling off the crust that is formed. However, if the crust is not peeled off but cultivated into the soil, the $\mathrm{Sr} 90$ incorporated in the crust will become progressively available to plants.

\section{EFFECT OF DEPTH OF PLACEMENT ON Sr 90 AVAILABILITY}

From time to time, deep plowing has been proposed as a possible means of dealing with soil surfaces that have been contaminated with $\mathrm{Sr} 90$. By this procedure, the contaminated surface is placed at a depth in the soil from which the Sr 90 is presumably less available to crops. In support of the idea, Guliakin and Yudintseva (1957) have found that the depth of placement of Sr 90 has a large influence on its uptake by wheat plants. They found that a given amount of Sr 90 was about 50 per cent less available at a depth of 6 inches than at a depth of 2 inches. In the experiments to be described here, the uptake of Sr 90 by barley, as influenced by depth of placement, was studied in the lysimeters at Davis, California. The studies were conducted with Columbia very fine sandy loam.

Because of the fact that the radioactivity was placed in bands at depths of from 2 inches to 4 feet, it was possible to gain information concerning the downward velocity of root growth under different irrigation procedures.

\section{Experiments and Results}

The lysimeters used were 5.5 feet deep and 27 inches in diameter. They were filled with Columbia very fine sandy loam; there was free drainage from the bottom of each container. The important chemical characteristics of Columbia v.f.s.l. are given in table 5. In all, 30 lysimeters were used in the experiments.

The Sr 90 bands were placed in the soil in the following way. The soil was dug out of the lysimeter to the appropriate depth and a carrier-free solution of $\mathrm{Sr} 90$ was added to the exposed surface at a rate such as to give $1 \mu \mathrm{c}$ per square inch. Following this, the soil that had been removed was put back into the lysimeter.

After placement of the $\mathrm{Sr} 90$ bands, the soils were fertilized with $\mathrm{NH}_{4} \mathrm{H}_{2} \mathrm{PO}_{4}$ at a rate equivalent to 90 pounds of nitrogen per acre. Three days before the experiments were started, all of the lysimeters were leached through with tap water. Thus it was assumed that all of the soils were at field capacity at the time the barley was planted.

On June 7, 1957, germinated seeds of barley were planted in the lysimeters ; there were 60 plants in each lysimeter or one plant per 9 square inches. During the first eight to nine days after planting, all of the lysimeters were 
irrigated lightly and any dead plants were replaced. After this period, only the lysimeters assigned for irrigation were irrigated. The general plan of the irrigation regime was as follows:

3 lysimeters, Sr 90 band at 2 inch depth, no irrigation

3 lysimeters, Sr 90 band at 2 inch depth, frequent irrigation

3 lysimeters, Sr 90 band at 1 foot depth, no irrigation

3 lysimeters, Sr 90 band at 1 foot depth, frequent irrigation

3 lysimeters, Sr 90 band at 2 foot depth, no irrigation

3 lysimeters, Sr 90 band at 2 foot depth, frequent irrigation

3 lysimeters, Sr 90 band at 3 foot depth, no irrigation

3 lysimeters, Sr 90 band at 3 foot depth, frequent irrigation

3 lysimeters, Sr 90 band at 4 foot depth, no irrigation

3 lysimeters, Sr 90 band at 4 foot depth, frequent irrigation

Where the lysimeters received "frequent irrigation," water was applied at a rate such as to maintain the soils near field capacity.

On the fourth day after planting, a systematic sampling of leaves was initiated. Ten leaf samples were taken at random from each lysimeter. When the plants were small, only the upper half of a leaf was taken; later on the whole leaf was taken.

After each sampling the leaves were assayed for radioactivity. When the count of the sample had reached or passed a value twice the background count, the sampling of the plants in the corresponding lysimeter was stopped. The double background count was arbitrarily taken as an indication that a number of roots had reached the $\mathrm{Sr} 90$ band. In figure 7, the time required for the roots to reach the Sr 90 band was plotted against the depth of the band.

The barley plants were harvested on August 1-2, 1957, when the vegetative part of the plants appeared to be at its maximum growth. The dry weights $\left(60-65^{\circ} \mathrm{C}\right)$ of the plant tops from each lysimeter are presented in table 6 . At the time of harvesting, representative samples of tillers from each tank were taken and split up into lower leaves, upper leaves, stems and heads. These plant parts were assayed for radioactivity. From the assay, the total uptake of Sr 90 by the tops as well as by the individual parts was calculated. In figure 8 the uptake by the tops, expressed as $\mathrm{m} \mu \mathrm{c} \mathrm{Sr} 90$ per gram of dry plant material, is plotted against the depth to the Sr 90 band. In figure 9 the gross uptake by the tops, expressed as percentage of the $\mathrm{Sr} 90$ added to the soil, is plotted as function of depth to the $\mathrm{Sr} 90$ band. In figures 10 and 11 the radioactivity of the plant parts, expressed as $\mathrm{m} \mu \mathrm{c}$ Sr 90 per gram of dry plant material is plotted against depth to the Sr 90 band.

When the plants had been harvested, borings were taken in each lysimeter. An examination of the soil of the borings for radioactivity indicated that there was essentially no diffusion of the $\mathrm{Sr} 90$ from the bands during the course of the experiments. 


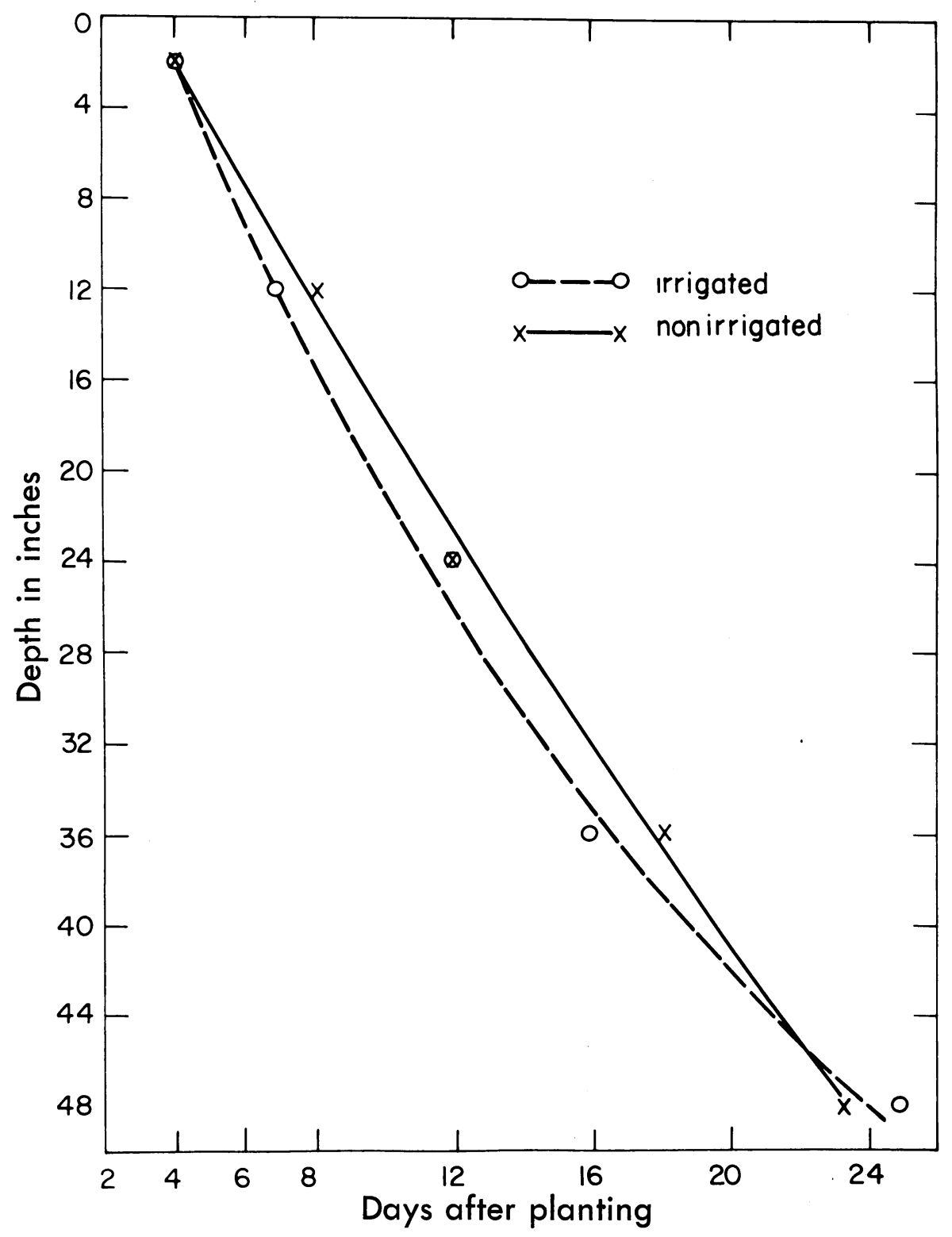

Fig. 7. Root growth in depth related to time. 


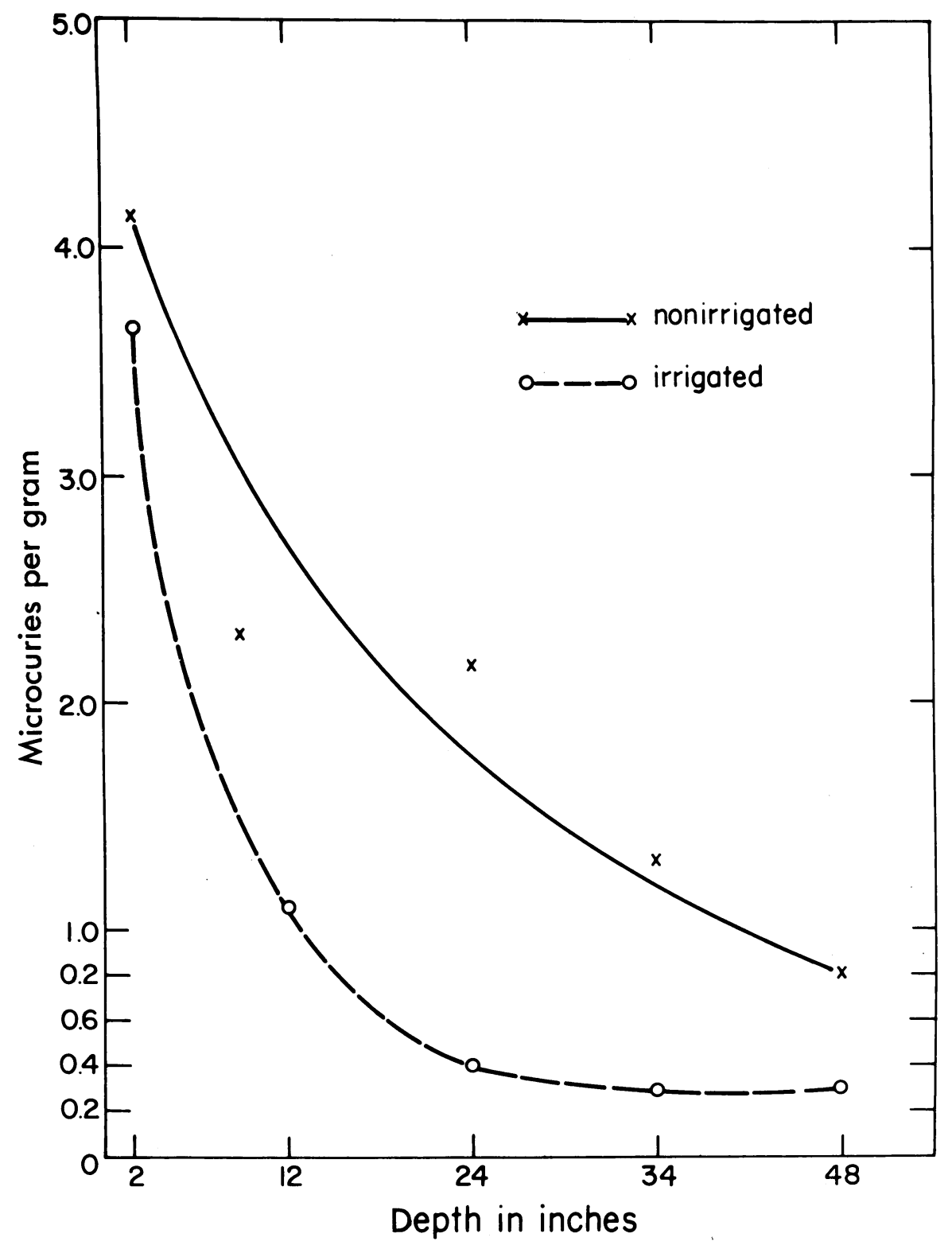

Fig. 8. Sr 90 taken up from different depths (m $\mu$ c per gram dry plant material). 


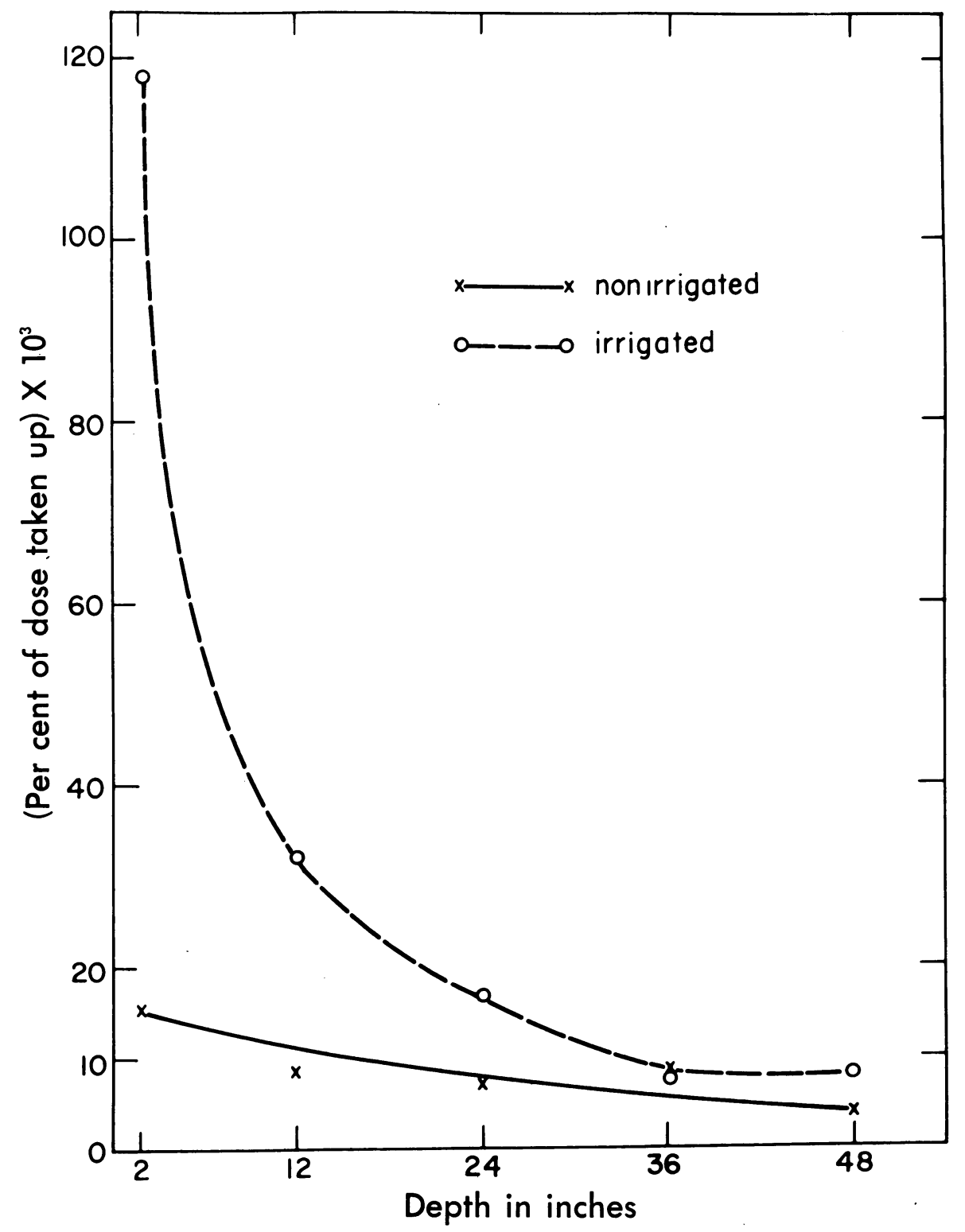

Fig. 9. Per cent of sr 90 dose taken up by barley from different depths. 


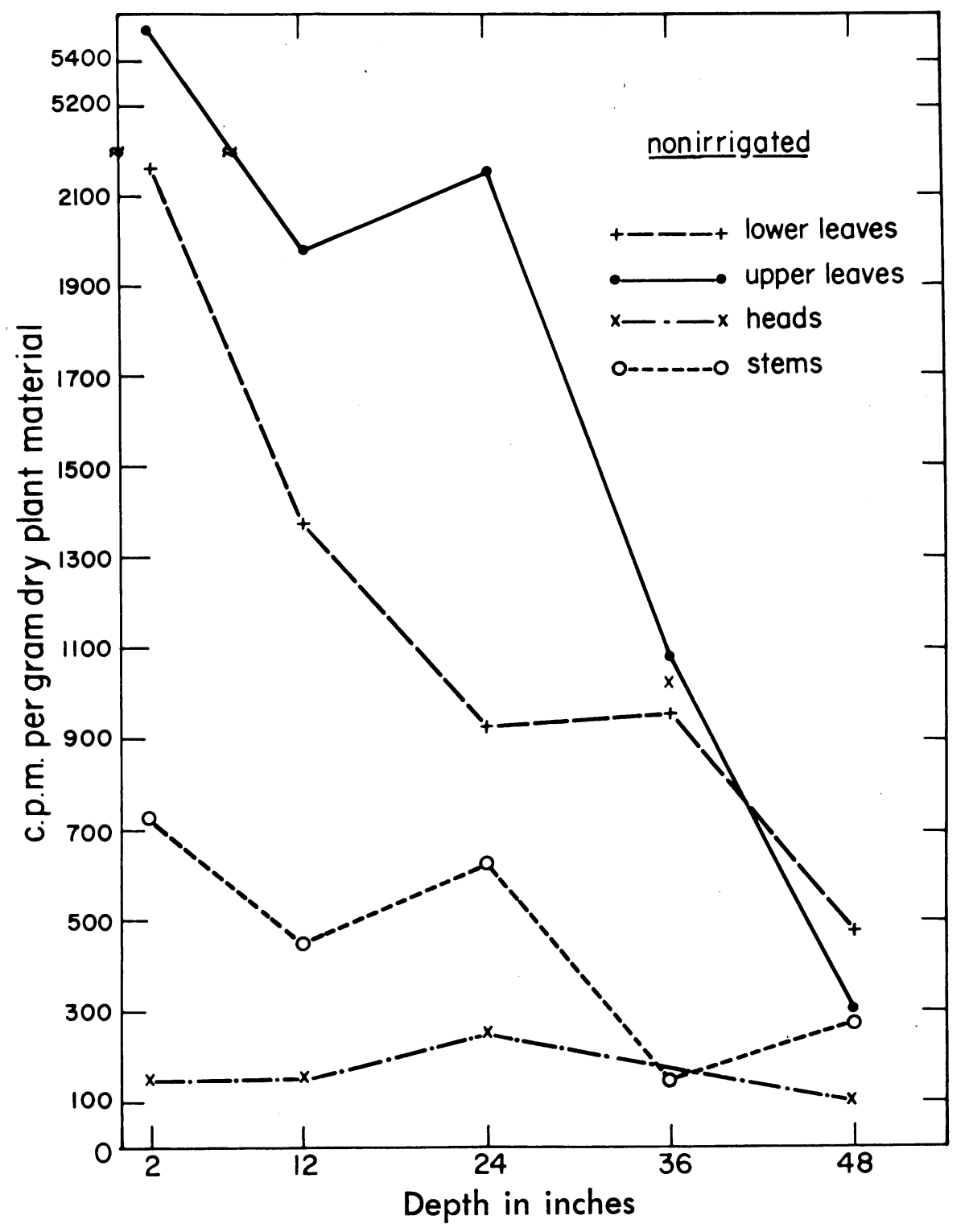

Fig. 10. Distribution of $\mathrm{Sr} 90$ within the plants, nonirrigated. 


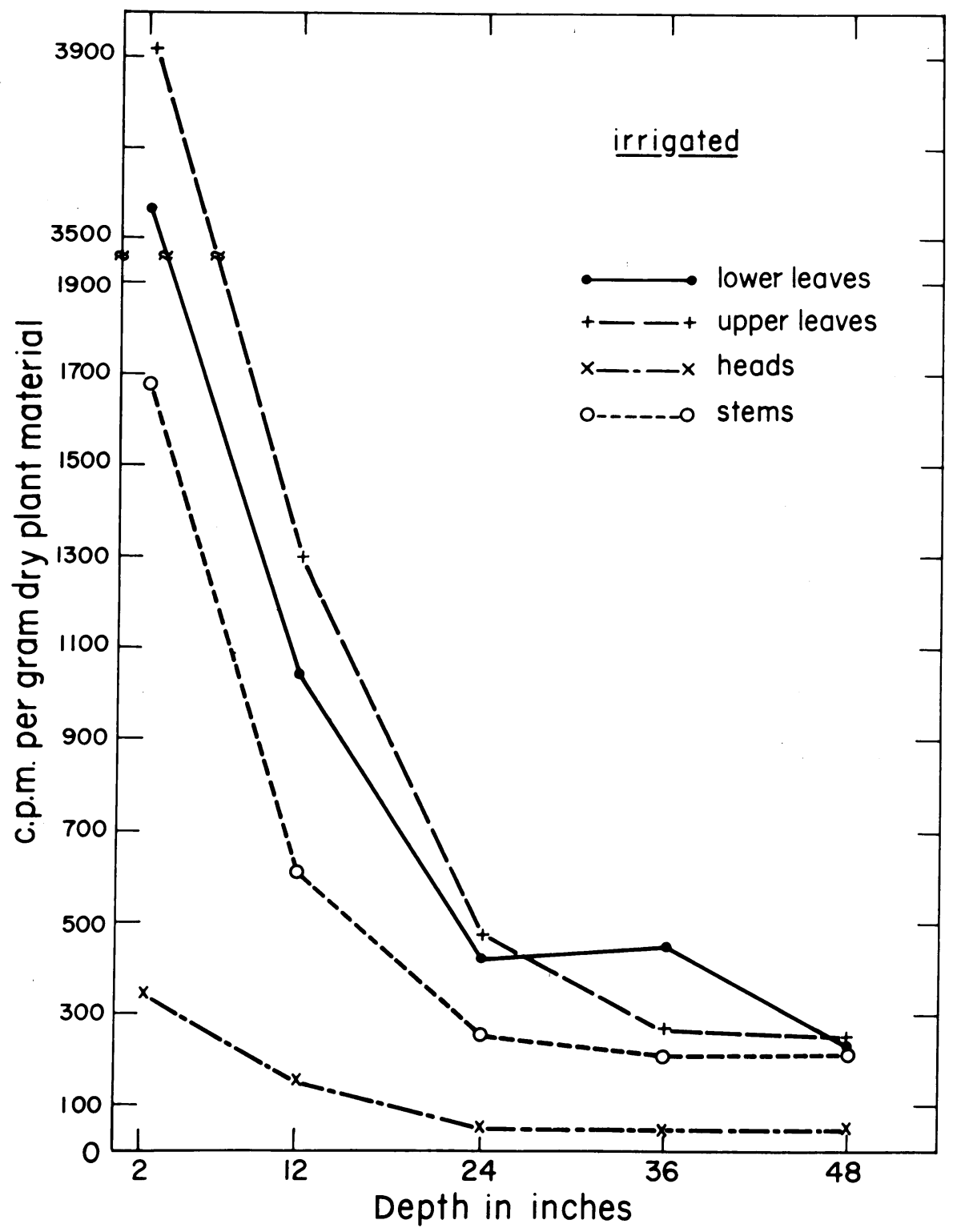

Fig. 11. Distribution of Sr 90 within the plants, irrigated. 


\section{Discussion and Conclusions}

The data of figure 7 reveal that the rate of downward growth of the barley roots was independent of the water treatment during the growing season. That is, in spite of the fact that the roots of the barley in the irrigated lysimeters were always well supplied with water and nutrients in the upper foot of the soil, the rate of downward growth was essentially the same as that in the nonirrigated lysimeters where the roots had to grow downward in order to obtain water. In both instances the rate of growth in depth was approximately linear with time and amounted to about 2 inches per day. These results are in general agreement with the findings of Conrad and Veihmeyer (1929).

As may be seen from table 6 and figure 8 , the irrigated plants, which showed the largest vegetative growth, contained less Sr 90 per gram of dry material than the nonirrigated plants. This was true at all depths of the $\mathrm{Sr} 90$ band, but the difference was not very pronounced when the Sr 90 band was at a depth of 2 inches.

The content of Sr 90 per gram of dry material decreased with depth of placement of the band for both the irrigated and nonirrigated plants. With the irrigated plants, the uptake per gram of dry plant material fell off quite rapidly with depth of placement to a depth of about 2 feet, below which it remained nearly constant down to 4 feet (figure 8 ). If this pattern should prove characteristic of other plants and soils, deep plowing, whereby a $\mathrm{Sr} 90$ contaminated surface is placed at a depth of 2 feet or more, should be an effective measure against the introduction of the isotope into food chains.

From figure 9 it is evident that the gross uptake of $\mathrm{Sr} 90$, expressed as percentage of that added to the soil, was generally higher for the irrigated plants. Also, the difference in uptake was very pronounced for the shallow depths. The gross uptake by the irrigated plants fell off rapidly with depth of placement. The gross uptake for the nonirrigated plants, however, was not greatly affected by the depth of placement of the isotope. In general, the gross uptake was considerably less than 0.1 per cent of the $\mathrm{Sr} 90$ added to the soil.

With both the irrigated and nonirrigated plants (see figures 10 and 11), the concentration of Sr 90 per gram of dry plant material assumed the following sequence among the various plant parts:

$$
\text { upper leaves }>\text { lower leaves }>\text { stems }>\text { heads }
$$

The significant concentration of $\mathrm{Sr} 90$ in the grain of the nonirrigated plants for the 2-inch depth of placement is notable because at the time the heads were formed in these plants the soil at the 2 -inch depth was quite dry. Thus the $\mathrm{Sr} 90$ must have been brought into the grain by translocation or by its absorption from very dry soil. Unfortunately, it is not possible to conclude further concerning these interesting possibilities. 


\section{LITERATURE CITED}

ConRad, J. P., and F. J. Veihmeyer

1929. Root development and soil moisture. Hilgardia 4(4):113.

Guliakin, I. V., and E. V. Yudintseva

1957. On the behavior of fission products in soil. Academy of Sciences of the U.S.S.R. (Translated from Russian and published by the U. S. Atomic Energy Commission.)

JACOBSON, L., and R. OVERSTREET

1947. The uptake by plants of plutonium and some products of nuclear fission adsorbed on soil colloids. Soil Science $65(2): 129-34$.

KrishNamoORTHY, C., and R. OverstreET

1950. An experimental evaluation of ion exchange relationships. Soil Science 69: 41-53.

Martin, R. P., P. Newbould, and R. Scott Russell

1957. Discrimination between strontium and calcium in plants and soils. International Conference on Radioisotopes in Scientific Research, Paris. UNESCO/NS/RIC/175.

NEEL, J. W., et al.

1953. Soil-plant interrelationships with respect to the uptake of fission products. Report No. UCLA 247 of Contract No. AT-04-1-6en 12 with the U. S. Atomic Energy Commission.

OVERSTREET, R.

1956. Decontamination of soils containing salt and radioactive elements. Progress Report of Contract AT(11-1) Project 23 with the U. S. Atomic Energy Commission.

SCHUlz, R. K., R. OverstreET, and K. L. BABCOCK

1958. On the soil chemistry of radio-strontium. Hilgardia $27(13): 333-42$. 
TABLE 1

ANALYSES OF SOIL SAMPLES FROM BURRIS PARK AREA

\begin{tabular}{|c|c|c|c|c|c|c|c|c|c|c|c|}
\hline \multirow{2}{*}{$\begin{array}{c}\text { Depth } \\
\text { of soil } \\
\text { (inches) }\end{array}$} & \multirow{2}{*}{ Boring no. } & \multirow{2}{*}{$\begin{array}{c}\mathrm{pH} \\
1: 5 \\
\text { susp. }\end{array}$} & \multicolumn{4}{|c|}{$\begin{array}{l}\text { Soluble cations } \\
\text { m.e. per } 100 \mathrm{gm}\end{array}$} & \multicolumn{4}{|c|}{$\begin{array}{l}\text { Exchangeable cations } \\
\text { m.e. per } 100 \mathrm{gm}\end{array}$} & \multirow{2}{*}{$\begin{array}{c}\text { Exchange } \\
\text { capacity } \\
\text { m.e./100 gm } \\
\left(\mathrm{NH}_{4} \mathrm{Ac}\right)\end{array}$} \\
\hline & & & $\mathrm{Ca}$ & $\mathbf{M g}$ & $\mathrm{Na}$ & $\mathbf{K}$ & $\mathrm{Ca}$ & $\mathbf{M g}$ & $\mathrm{Na}$ & $\mathbf{K}$ & \\
\hline $0-12$ & 1. & 7.7 & 0.38 & 0.09 & 0.08 & 0.06 & 14.3 & 3.2 & 1.41 & 0.79 & 12.9 \\
\hline $0-12$ & $2 \ldots$ & 7.7 & 0.42 & 0.09 & 0.08 & 0.05 & 15.0 & 3.3 & 1.45 & 0.64 & 12.9 \\
\hline $0-12$ & $3 \ldots$ & 7.6 & 0.28 & 0.07 & 0.05 & 0.08 & 14.1 & 2.9 & 0.10 & 0.73 & 12.2 \\
\hline $0-12$ & $4 \ldots$ & 7.8 & 0.32 & 0.09 & 0.08 & 0.05 & 15.0 & 3.3 & 0.13 & 0.58 & 12.8 \\
\hline $0-12$ & Composite.. & 7.9 & 0.37 & 0.09 & 0.07 & 0.05 & 15.3 & 2.9 & 0.38 & 0.60 & 12.2 \\
\hline $12-24$ & $1 \ldots \ldots \ldots \ldots \ldots$ & 7.8 & 0.24 & 0.06 & 0.08 & 0.01 & 13.9 & 3.0 & 1.24 & 0.34 & 11.9 \\
\hline $12-24$ & $2 \ldots$ & 7.5 & 0.22 & 0.06 & 0.12 & 0.05 & 12.9 & 3.0 & 1.01 & 0.18 & 11.4 \\
\hline $12-24$ & $3 \ldots$ & 7.5 & 0.13 & 0.03 & 0.08 & 0.01 & 10.4 & 2.0 & 0.17 & 0.14 & 8.9 \\
\hline $12-24$ & $4 \ldots$ & 7.4 & 0.16 & 0.02 & 0.06 & 0.01 & 12.6 & 2.6 & 0.15 & 0.17 & 11.1 \\
\hline $24-36$ & $1 \ldots$ & 7.5 & 0.14 & 0.05 & 0.08 & 0.01 & 11.0 & 3.6 & 0.56 & 0.17 & 10.0 \\
\hline $24-36$ & $2 \ldots$ & 7.2 & 0.13 & 0.05 & 0.08 & 0.01 & 9.9 & 2.7 & 0.14 & 0.10 & 8.9 \\
\hline $24-36$ & 3. & 7.4 & 0.08 & 0.02 & 0.08 & 0.01 & 8.1 & 2.5 & 0.15 & 0.10 & 7.0 \\
\hline $24-36$ & $4 \ldots \ldots$ & 7.0 & 0.18 & 0.09 & 0.08 & 0.01 & 11.1 & 3.2 & 0.11 & 0.11 & 9.8 \\
\hline
\end{tabular}

Soluble anions are predominantly $\mathrm{HCO}_{3}{ }^{-}$.

TABLE 2

ANALYSES OF' SOIL SAMPLES FROM HOPLAND AREA

\begin{tabular}{|c|c|c|c|c|c|c|c|c|c|c|c|}
\hline \multirow{2}{*}{$\begin{array}{l}\text { Depth } \\
\text { of soil } \\
\text { (inches) }\end{array}$} & \multirow{2}{*}{ Boring no. } & \multirow{2}{*}{$\begin{array}{c}\text { pH } \\
1: 5 \\
\text { susp. }\end{array}$} & \multicolumn{4}{|c|}{$\begin{array}{l}\text { Soluble cations } \\
\text { m.e. per } 100 \mathrm{gm}\end{array}$} & \multicolumn{4}{|c|}{$\begin{array}{c}\text { Exchangeable cations } \\
\text { m.e. per } 100 \mathrm{gm}\end{array}$} & \multirow{2}{*}{$\begin{array}{c}\text { Exchange } \\
\text { capacity } \\
\text { m.e./100 gm } \\
\left(\mathrm{NH}_{4} \mathrm{Ac}\right)\end{array}$} \\
\hline & & & $\mathrm{Ca}$ & $\mathbf{M g}$ & $\mathrm{Na}$ & $\mathbf{K}$ & $\mathrm{Ca}$ & $\mathbf{M g}$ & $\mathrm{Na}$ & $\mathbf{K}$ & \\
\hline $0-12$ & $1 \ldots \ldots \ldots \ldots \ldots \ldots$ & 6.0 & 0.04 & 0.07 & 0.03 & 0.01 & 6.6 & 6.7 & 0.04 & 0.29 & 13.5 \\
\hline $0-12$ & 2. & 5.9 & 0.04 & 0.06 & 0.03 & 0.01 & 7.1 & 8.5 & 0.04 & 0.29 & 14.9 \\
\hline $0-12$ & $3 \ldots \ldots \ldots \ldots \ldots \ldots$ & 5.9 & 0.04 & 0.06 & 0.03 & 0.01 & 6.4 & 7.1 & 0.05 & 0.19 & 13.4 \\
\hline $0-12$ & $\ldots \ldots \ldots \ldots \ldots$ & 5.9 & 0.05 & 0.09 & 0.03 & 0.01 & 6.7 & 7.2 & 0.07 & 0.20 & 13.9 \\
\hline $0-12$ & Composite.......... & 6.2 & 0.04 & 0.05 & 0.04 & 0.01 & 7.1 & 6.4 & 0.04 & 0.26 & 13.4 \\
\hline $12-24$ & $1 \ldots \ldots \ldots \ldots \ldots \ldots$ & 6.2 & 0.02 & 0.05 & 0.03 & 0.01 & 6.4 & 8.3 & 0.05 & 0.19 & 13.8 \\
\hline $12-24$ & $2 \ldots \ldots \ldots \ldots \ldots \ldots$ & 6.3 & 0.03 & 0.05 & 0.03 & 0.01 & 6.6 & 8.4 & 0.07 & 0.18 & 14.0 \\
\hline $12-24$ & $3 \ldots \ldots$ & 6.2 & 0.03 & 0.04 & 0.02 & 0.01 & 5.7 & 7.7 & 0.06 & 0.18 & 12.8 \\
\hline $12-24$ & $4 \ldots \ldots \ldots \ldots \ldots$ & 6.3 & 0.03 & 0.05 & 0.03 & 0.06 & 6.0 & 8.0 & 1.29 & 0.29 & 12.5 \\
\hline $24-36$ & $1 \ldots$ & 6.4 & 0.02 & 0.04 & 0.04 & 0.01 & 6.0 & 8.6 & 0.04 & 0.17 & 13.3 \\
\hline $24-36$ & $2 \ldots$ & 6.4 & 0.03 & 0.05 & 0.03 & 0.01 & 5.9 & 8.5 & 0.05 & 0.18 & 13.2 \\
\hline $24-36$ & $3 \ldots$ & 6.4 & 0.03 & 0.06 & 0.03 & 0.01 & 6.2 & 9.0 & 0.07 & 0.19 & 15.4 \\
\hline $24-36$ & $4 \ldots \ldots \ldots \ldots$ & 6.4 & 0.03 & 0.05 & 0.05 & 0.08 & 6.1 & 8.7 & 1.30 & 0.16 & 13.0 \\
\hline
\end{tabular}

Soluble anions are predominantly $\mathrm{HCO}_{3}{ }^{-}$. 
TABLE 3

PER CENT OF APPLIED Sr 90 RETAINED IN THE SOIL PROFILE AFTER TREATMENT WITH VARIOUS CHEMICALS AND IRRIGATION WITH 5 FEET OF WATER

Hopland Field Station

\begin{tabular}{|c|c|c|c|c|c|c|c|}
\hline \multicolumn{8}{|c|}{ Treatments and Plot Number } \\
\hline $\begin{array}{l}\text { Depth of soil } \\
\text { (inches) }\end{array}$ & $\begin{array}{c}1 \\
\text { Control }\end{array}$ & $\stackrel{2}{\mathrm{HCl}}$ & $\stackrel{3}{\mathrm{HCl}}$ & $\mathrm{H}_{2} \stackrel{4}{\mathrm{SO}_{4}}$ & $\stackrel{5}{\mathrm{CaCl}_{2}}$ & $\stackrel{6}{\mathrm{FeCl}_{3}}$ & $\stackrel{7}{\mathrm{NaCl}}$ \\
\hline $0-6$. & 87.4 & 11.1 & 11.6 & 63.1 & 38.9 & 11.7 & 76.8 \\
\hline $0-12$. & 92.8 & 27.3 & 24.7 & 80.6 & 63.7 & 21.7 & 90.7 \\
\hline $0-24$. & 97.4 & 52.7 & 43.6 & 94.0 & 86.4 & 49.0 & 98.3 \\
\hline $0-36$. & 100 & 71.7 & 56.0 & 100 & 95.6 & 77.0 & 100 \\
\hline
\end{tabular}

Burris Park Field Station

Treatments and Plot Number

\begin{tabular}{|c|c|c|c|c|c|c|c|}
\hline $\begin{array}{l}\text { Depth of soil } \\
\text { (inches) }\end{array}$ & $\stackrel{1}{\text { Control }}$ & $\stackrel{2}{\mathrm{HCl}}$ & $\stackrel{3}{\mathrm{HCl}}$ & $\mathrm{H}_{2} \mathrm{SO}_{4}$ & $\underset{\mathrm{CaCl}_{2}}{5}$ & $\mathrm{FeCl}_{3}$ & $\stackrel{7}{\mathrm{NaCl}}$ \\
\hline $0-6 \ldots \ldots \ldots$ & 97.0 & 22.2 & 49.3 & 64.1 & 62.0 & 9.6 & 94.8 \\
\hline $0-12$. & 100 & 64.6 & 85.8 & 83.5 & 85.2 & 59.7 & 98.0 \\
\hline $0-24$. & 100 & 99.8 & 100 & 99.6 & 97.4 & 88.4 & 99.5 \\
\hline $0-36$ & 100 & 100 & 100 & 100 & 100 & 100 & 100 \\
\hline
\end{tabular}

The treatments were made at the rates: $\mathrm{HCl}, 14.9$ tons per acre; $\mathrm{FeCl}_{3}, 22.1$ tons per acre; $\mathrm{H}_{2} \mathrm{SO}_{4}, 20$ tons per acre; $\mathrm{CaCl}_{2}, 22.6$ tons per acre; and $\mathrm{NaCl}, 23.8$ tons per acre.

TABLE 4

UPTAKE OF Sr 90 BY TOPS OF BARLEY PLANTS GROWN IN ASPHALT-TREATED SOIL; RESULTS EXPRESSED AS PER CENT OF CONTROL

\begin{tabular}{|c|c|c|}
\hline Emulsion applied & $\begin{array}{l}18 \text { days after } \\
\text { planting }\end{array}$ & $\begin{array}{l}67 \text { days after } \\
\text { planting }\end{array}$ \\
\hline 0 & 100 & 100 \\
\hline Lakold............. & 28 & 58.5 \\
\hline Bitusize L3L $\ldots \ldots \ldots$ & 78 & 70.4 \\
\hline$\ldots \ldots \ldots \ldots \ldots \ldots \ldots \ldots$ & 85 & 73.5 \\
\hline
\end{tabular}

The plants were grown in galvanized tubs, each containing 110 pounds of Columbia soil. In each instance the surface area of the soil was 400 square inches. The $\mathrm{Sr} 90$ was applied at the rate of $1 \mu \mathrm{c}$ per square inch.

At 67 days after planting, the tops of the control plants contained 0.51 per cent of the applied Sr 90 . 
TABLE 5

ANALYSIS OF COLUMBIA VERY FINE SANDY LOAM SOIL USED IN LYSIMETER STUDY

\begin{tabular}{|c|c|c|c|c|c|c|c|c|c|}
\hline \multirow{2}{*}{$\mathrm{pH} 1: 5$ suspension } & \multicolumn{4}{|c|}{$\begin{array}{l}\text { Soluble cations } \\
\text { m.e. per } 100 \mathrm{gm}\end{array}$} & \multicolumn{4}{|c|}{$\begin{array}{l}\text { Exchangeable cations } \\
\text { m.e. per } 100 \mathrm{gm}\end{array}$} & \multirow{2}{*}{$\begin{array}{c}\text { Exchange } \\
\text { capacity } \\
\text { m.e./100 gm } \\
\left(\mathrm{NH}_{4} \mathrm{Ac}\right)\end{array}$} \\
\hline & $\mathrm{Ca}$ & $\mathbf{M g}$ & $\mathrm{Na}$ & $\mathbf{K}$ & $\mathrm{Ca}$ & $\mathbf{M g}$ & $\mathrm{Na}$ & $\mathbf{K}$ & \\
\hline 6.6. & 0.14 & 0.07 & 0.05 & 0.06 & 13.5 & 3.70 & 0.83 & 0.15 & 13.9 \\
\hline
\end{tabular}

TABLE 6

YIELD OF BARLEY IN IRRIGATED AND NONIRRIGATED LYSIMETERS WHICH HAD A BAND OF Sr 90 AT DIFFERENT DEPTHS IN THE SOIL. RESULTS ARE EXPRESSED AS GRAMS OF OVENDRY $\left(60^{\circ}-65^{\circ} \mathrm{C}\right)$ MATERIAL

\begin{tabular}{|c|c|c|c|c|}
\hline $\begin{array}{c}\text { Depth of Sr } 90 \text { band } \\
\text { (inches) }\end{array}$ & $\begin{array}{l}\text { Wt. of tops, } \\
\text { irrigated } \\
\text { lysimeters }\end{array}$ & Average & $\begin{array}{l}\text { Wt. of tops, } \\
\text { nonirrigated } \\
\text { lysimeters }\end{array}$ & Average \\
\hline$\ldots \ldots$ & $\begin{array}{l}212.4 \\
179.2 \\
123.5\end{array}$ & 171.7 & $\begin{array}{l}19.40 \\
15.31 \\
24.97\end{array}$ & 19.89 \\
\hline $12 \ldots \ldots \ldots$ & $\begin{array}{l}138.3 \\
214.0 \\
132.5\end{array}$ & 161.6 & $\begin{array}{l}34.33 \\
20.34 \\
13.36\end{array}$ & 22.68 \\
\hline $24 \ldots \ldots$ & $\begin{array}{l}156.3 \\
154.4 \\
152.7\end{array}$ & 154.5 & $\begin{array}{l}22.99 \\
16.69 \\
13.98\end{array}$ & 17.89 \\
\hline 35 . & $\begin{array}{l}119.2 \\
200.4 \\
173.3\end{array}$ & 164.3 & $\begin{array}{l}50.73 \\
25.40 \\
32.66\end{array}$ & 36.26 \\
\hline 48. & $\begin{array}{l}132.5 \\
160.7 \\
154.6\end{array}$ & 149.3 & $\begin{array}{l}32.27 \\
23.49 \\
24.69\end{array}$ & 26.82 \\
\hline
\end{tabular}



The journal Hilgardia is published at irregular intervals, in volumes of about 600 pages. The number of issues per volume varies.

Subscriptions are not sold. The periodical is sent as published only to libraries, or to institutions in foreign countries having publications to offer in exchange.

You may obtain a single copy of any issue free, as long as the supply lasts; please request by volume and issue number from:

\section{Agricultural Publications \\ University of California \\ Berkeley 4, California}

The limit to nonresidents of California is 10 separate issues on a single order. A list of the issues still available will be sent on request.

In our publications it is sometimes convenient to use trade names of products or equipment rather than scientific identifications. In so doing it is unavoidable in some cases that similar products which are on the market under other trade names may not be cited. No endorsement of named products is intended nor is criticism implied of similar products which are not mentioned. 